\title{
USING SOME INSECTICIDES FOR CONTROLLING COTTON AND WATERMELON APHID, APHIS GOSSYPII GLOVER ON CUCUMBER PLANTS REFERRING TO THE YIELD
}

\author{
MONA A. MOHAMED and H. B. HOMAM
}

Plant Protection Research Institute, ARC, Dokki, Giza, 12618 Egypt

(Manuscript received 17 May 2011)

\begin{abstract}
Field experiments were conducted to investigate the effectiveness of five insecticides (Carbosulfan 25\% WP, Acetamiprid $20 \%$ SP, Imidacloprid 35\% SC, Pyrethrins 5\% EC and Mineral oil $96 \%$ EC) on the cotton and watermelon aphid, Aphis gossypii Glover on cucumber plants at Behira and Benisuef governorates in Egypt during two successive seasons 2009 and 2010 and evaluated their effects on yield.

The obtained data showed that, Acetamiprid, Carbosulfan and Imidacloprid recorded the lowest population of $A$. gossypii in both Behira and Benisuef in 2009 and 2010 during summer plantation seasons, while Mineral oil gave intermediate effect in reducing population of $A$. gossypii. On the other hand, Pyrethrins as a natural plant origin insecticide showed the least effect in reducing population of $A$. gossypii (12.81 \& 9.30 "Behira" and 8.72 \& 9.81 "Benisuef " individuals/leaf/season) in 2009 and 2010 during summer plantation seasons, respectively. Significant differences were proved between treated and untreated plots in the two studied seasons.

The highest cucumber yield was collected from plots treated with Acetamiprid followed by Carbosulfan, Imidacloprid, Mineral oil and Pyrethrins which gave the lowest yield. The results concluded that Acetamiprid proved to be the most effective insecticide against $A$. gossypii with highest cucumber yield.

As for persistence, data clearly indicated that Acetamiprid, Carbosulfan and Imidacloprid showed the longest persistent behaviour and showed the highest reduction in aphid population till the $10^{\text {th }}$ day relaxation period after application $(88.06,75.01$ "Acetamiprid" and 74.93\% \& 87.22 "Carbosulfan" , 80.82 and $75.52 \%$ "Imidacloprid") in both Behira and Benisuef during summer season 2010, respectively. On the other hand, Mineral oil and Pyrethrins caused the least reduction against $A$. gossypii population after ten days of relaxation period, i.e. (69.81 and $48.33 \%$ "Mineral oil" \& 68.32 and $44.35 \%$ "Pyrethrins") the same season, respectively.
\end{abstract}




\section{INTRODUCTION}

Cucumber, Cucumis sativus L. is one of the most important cucurbita vegetable crops in Egypt, as it cultivated under different environmental conditions, open fields and greenhouses for local consumption and exportation. It cultivated in wide areas either old lands or newly reclaimed lands.

During its vegetative growth in summer plantations, plants are usually attacked by several pests, of which the cotton and watermelon aphid, Aphis gossypii Glover. Aphids are small and soft-bodies insects with considerable morphological polymorphism, such as intraspecies colour variation, apterous (wingless) and alate (winged) adults, etc. Of all aphid subfamilies, Aphididae is the most diverse and exceptionally host specific, except for a number of species that are polyphagous agricultural pests (Von Dohlen et. al. , 2006, Farag and Gesraha, 2007 and Lu et. al. , 2008). Aphid feeding causes an alteration of plant source-sink relationships (Girousse et. al. , 2005), the induction of premature leaf senescence (Pegadaraju et. al. , 2005), secondary pathogen infection through fungal growth on aphid honeydew, and the transmission of plant viruses (Rana et. al. , 2007 and Toperkaygin et. al. , 2008). In addition to damages caused directly through feeding behaviour, the sooty mould induced by the great amount of aphid honeydew, will hamper photosynthesis, leaving plants wither rapidly. Furthermore, the short generation time and impressive fecundity of aphids accelerate the vicious circle causing considerable economical loss (Blackman and Eastop, 2000).

Although chemical control of aphids is an old tool, yet it is still necessary to be used as an effective method against high aphid populations.

The two objectives of the present work were as follows (1) to study the effect of weekly applications of five insecticides on aphid population and on cucumber yield (2) to compare efficacy of the tested insecticides on the population of aphids.

\section{MATERIALS AND METHODS}

Field trials were conducted in fields of commercial cucumber at Behira and Benisuef governorates, in two successive summer seasons 2009 and 2010. The variety "Medina" cucumber, Cucumis sativus L., was planted during the first week of May, in a randomized complete block design with four replicates/treatment. Each plot $\left(16 \mathrm{~cm}^{2}\right)$ consisted of four rows of five meters each, 0.8 wide with plants spaced 0.5 $\mathrm{m}$ apart within rows, and the usual horticultural practices were employed to the crop. So in order to achieve these trials the following two experiments were designed. 


\section{The first experiment:}

The first experiment was carried out to study the effect of some insecticides on the population of $A$. gossypii and on cucumber yield during two successive summer bseasons of 2009 and 2010. The tested insecticides were applied weekly as foliar sprays (five sprays), started from germination of the plants until the beginning of harvest. To evaluate the effectiveness of tested insecticides on aphids, the numbers of aphid apterous were counted weekly on 25 leaves randomizely picked from old, young and newly leaves from each plot. Fruits were harvested twice weekly or as needed and marketable fruits were weighted for each plot throughout the harvesting period (extended to 45 days approximately). Resulted cucumber fruits of each treatment were collected and weighted to estimate the final yields. The obtained data were statistically analyzed using the analysis of variance and separation of means was determined by LSD test at 0.05 level of significance by Duncan's multiple range test (Duncan, 1955).

\section{The second experiment:}

It aimed to study the efficacy of the tested insecticides on the population of aphids. The insecticides were applied on $7^{\text {th }}$ June in the summer of 2010, at as a single foliar spray. The numbers of apterous aphids were counted pre-treatment and after 1, 3, 7 and 10 days of spray. The reduction for each treatment was calculated according to Henderson's formula (Henderson \& Tilton, 1955).

However the tested insecticides and their rates of application/100 litre of water were as follows:

1. Marshal (Carbosulfan) $25 \%$ WP at $150 \mathrm{~g} / 100$ litre of water.

2. Vapcomore (Acetamiprid) $20 \% \mathrm{SP}$ at $25 \mathrm{~g} / 100$ litre of water.

3. Imidor (Imidacloprid) $35 \% \mathrm{SC}$ at $75 \mathrm{ml} / 100$ litre of water.

4. Pyrethrium (Pyrethrins) $5 \% \mathrm{EC}$ at $110 \mathrm{ml} / 100$ litre of water.

5. Versal (Mineral oil) $96 \%$ EC at $1.5 \mathrm{~L} / 100$ litre of water.

6. Control (check) which was free of any pesticides.

The application was conducted using a Knapsack sprayer with an adjustable cone nozzle calibrated to deliver 400 liters/Feddan of the diluted spray. The plots of the control were sprayed with water only. 


\section{RESULTS AND DISCUSSION}

\section{Seasonal efficacy of some insecticides on A. gossypii populations and on cucumber yield:}

Data in Table (1) showed the response of $A$. gossypii infesting cucumber plants to some insecticides during two summer seasons of 2009 and 2010 at Behira and Benisuef governorates.

Duncan's analysis classified the tested insecticides into three categories. Pyrethrins as a natural plant origin insecticide recorded least effective in reducing population of $A$. gossypii (12.81 \& 9.30 individuals/leaf/season) and (8.72 \& 9.81 individuals/leaf/season) in both Behira and Benisuef in 2009 \& 2010 during summer plantation, respectively.

On the other hand, Acetamiprid, Carbosulfan and Imidacloprid were highly in reducing population of $A$. gossypii to 3.26\&2.19 and 2.78\&1.77" "Carbosulfan", 4.02\&2.85 and 3.12\&2.05 "Acetamiprid" and 4.50\&3.28 and 3.56\&2.28 "Pyrethrins" individuals/leaf/season in both Behira and Benisuef in 2009 \& 2010 during summer plantation, respectively. While mineral oil showed intermediate and reduced on population of $A$. gossypii to $8.67 \& 6.91$ and $7.59 \& 6.81$ individuals/leaf/ season of the same seasons, respectively.

Significant differences were found between treated and untreated plots in the two studied seasons.

In general, the Mineral oil and Pyrethrins treatments were achieved satisfactory effects against aphid population in the two studied seasons comparing with other treatments.

Table 1. Effect of tested insecticides on Aphis gossypii Glover population on cucumber plants during summer plantation seasons of 2009 and 2010 in Behira and Benisuef Governorates.

\begin{tabular}{|c|c|c|c|c|c|c|}
\hline \multirow{2}{*}{ Treatments } & \multicolumn{6}{|c|}{ Mean No. of aphid/leaf/season } \\
\cline { 2 - 7 } & \multicolumn{3}{|c|}{ Behira } & \multicolumn{3}{c|}{ Benisuef } \\
\cline { 2 - 7 } & 2009 & 2010 & $\begin{array}{c}\text { General } \\
\text { mean }\end{array}$ & 2009 & 2010 & $\begin{array}{c}\text { General } \\
\text { mean }\end{array}$ \\
\hline Carbosulfan 25\% WP & $4.02^{\mathrm{d}}$ & $2.85^{\mathrm{d}}$ & 3.44 & $3.12^{\mathrm{d}}$ & $2.05^{\mathrm{d}}$ & 2.59 \\
\hline Acetamiprid 20\% SP & $3.26^{\mathrm{d}}$ & $2.19^{\mathrm{d}}$ & 2.73 & $2.78^{\mathrm{d}}$ & $1.77^{\mathrm{d}}$ & 2.28 \\
\hline Imidacloprid 35\% SC & $4.50^{\mathrm{d}}$ & $3.28^{\mathrm{d}}$ & 3.89 & $3.56^{\mathrm{d}}$ & $2.28^{\mathrm{d}}$ & 2.92 \\
\hline Pyrethrins 5\% EC & $12.81^{\mathrm{b}}$ & $9.30^{\mathrm{b}}$ & 11.06 & $10.90^{\mathrm{b}}$ & $8.72^{\mathrm{b}}$ & 9.81 \\
\hline Mineral oil 96\% EC & $8.67^{\mathrm{c}}$ & $6.91^{\mathrm{c}}$ & 7.74 & $7.59^{\mathrm{c}}$ & $6.81^{\mathrm{c}}$ & 7.20 \\
\hline Untreated & $29.39^{\mathrm{a}}$ & $23.08^{\mathrm{a}}$ & 26.24 & $24.90^{\mathrm{a}}$ & $21.65^{\mathrm{a}}$ & 23.28 \\
\hline L.S.D. at 0.05 & 2.05 & 1.29 & - & 1.78 & 1.21 & - \\
\hline
\end{tabular}

Means in each column followed by the same letter $(s)$ are not significantly different $(P=0.05$ : Duncan's (1955) multiple range test) 


\section{Effect of single application of some insecticides on A. gossypii;}

Data in Tables ( 2 and 3 ) clearly indicated that the tested insecticides showed various efficiency on aphids.

Data in Table (2) proved that Acetamiprid proved most effective insecticides against aphids, the highest initial mortality occurred after 24 hours of treatment (98.36\%), and gave a continuous reduction in aphid population for 10 days of treatment Table (2). The general mean reduction was (94.01\%) indicating remarkable residual action of Acetamiprid. The treatment with Imidacloprid and Carbosulfan showed similar or nearly results as Acetamiprid, they showed 97.79 and $96.93 \%$ initial mortality, respectively. The treatment with Mineral oil caused $83.74 \%$ initial mortality and $76.82 \%, 72.44 \%$ and $69.81 \%$ reduction in aphid population after 3, 7 and 10 days, respectively. The residual effect of the Mineral oil has proved by reducing the aphid population during ten days after treatment by an average of $75.70 \%$ reduction. Pyrethrins gave a median effect on aphid population during the same post-treatment period, they recorded (69.89\%) initial mortality and $64.44 \%, 51.27 \%$ and $48.33 \%$ mortality in aphid population after 3, 7 and 10 days, respectively, with an average of $58.48 \%$ reduction.

The results obtained in Table (3) were close to those tabulated in Table (2), indicating the similarity in the effect of the tested materials at the two governorates. One day of application showed that Acetamiprid caused reduction in the population of A. gossypii of $98.08 \%$, followed by Imidacloprid (96.97\%), Carbosulfan $(94.73 \%)$, Mineral oil (82.38\%), while Pyrethrins gave the lowest reduction (68.99\%). 
Table 2. Pesticidal activity of some control agents against Aphis gossypii Glover on cucumber plants during summer plantation, season 2010 in Behira governorate.

\begin{tabular}{|c|c|c|c|c|c|c|c|c|c|c|c|c|}
\hline \multirow[b]{2}{*}{ Treatments } & \multirow{2}{*}{$\begin{array}{c}\text { Rate/ } \\
100 \text { litre }\end{array}$} & \multicolumn{11}{|c|}{ Number of aphids/100 leaves and \%reduction after different days from spray } \\
\hline & & $\begin{array}{l}\text { Pre- } \\
\text { spray }\end{array}$ & $\begin{array}{l}\text { One } \\
\text { day }\end{array}$ & $\begin{array}{l}\text { \%reducti } \\
\text { on }\end{array}$ & $\begin{array}{c}\text { Three } \\
\text { days }\end{array}$ & $\begin{array}{l}\text { \%reducti } \\
\text { on }\end{array}$ & $\begin{array}{c}\text { Seven } \\
\text { days }\end{array}$ & $\begin{array}{c}\text { \%reducti } \\
\text { on }\end{array}$ & Ten days & $\begin{array}{l}\text { \%reducti } \\
\text { on }\end{array}$ & $\begin{array}{c}\text { General } \\
\text { mean }\end{array}$ & $\begin{array}{c}\text { General } \\
\text { \%reducti } \\
\text { on }\end{array}$ \\
\hline $\begin{array}{c}\text { Carbosulfan } \\
25 \% \text { WP }\end{array}$ & $150 \mathrm{~g}$ & 1322 & $76^{d}$ & 96.93 & $193^{d}$ & 92.42 & $359^{d}$ & 86.90 & $730^{d}$ & 75.01 & 339.5 & 87.81 \\
\hline $\begin{array}{c}\text { Acetamiprid } \\
20 \% \mathrm{SP}\end{array}$ & $25 \mathrm{~g}$ & 1273 & $39^{f}$ & 98.36 & $93^{e}$ & 96.21 & $174^{f}$ & 93.41 & $336^{\mathrm{e}}$ & 88.06 & 160.5 & 94.01 \\
\hline $\begin{array}{c}\text { Imidacloprid } \\
35 \% \text { SC }\end{array}$ & $75 \mathrm{ml}$ & 1350 & $56^{e}$ & 97.79 & $166^{d}$ & 93.62 & $335^{e}$ & 88.03 & $748^{d}$ & 74.93 & 326.25 & 88.59 \\
\hline $\begin{array}{c}\text { Pyrethrins } 5 \% \\
\text { EC }\end{array}$ & $110 \mathrm{ml}$ & 1445 & $815^{b}$ & 69.89 & $990^{\mathrm{b}}$ & 64.44 & $1460^{\mathrm{b}}$ & 51.27 & $1650^{b}$ & 48.33 & 1228.75 & 58.48 \\
\hline $\begin{array}{c}\text { Mineral oil } 96 \% \\
\text { EC }\end{array}$ & $1.5 \mathrm{~L}$ & 1346 & $410^{c}$ & 83.74 & $601^{c}$ & 76.82 & $769^{c}$ & 72.44 & $898^{c}$ & 69.81 & 669.5 & 75.70 \\
\hline Untreated & - & 1500 & $2810^{a}$ & - & $2890^{a}$ & - & $3110^{a}$ & - & $3315^{a}$ & - & - & - \\
\hline L.S.D. at 0.05 & - & - & 8.98 & - & 40.15 & - & 9.41 & - & 38.11 & - & - & - \\
\hline
\end{tabular}

Means in each column followed by the same letter ( $s$ ) are not significantly different ( $P=0.05$ : Duncan's (1955) multiple range test) 
Table 3. Pesticidal activity of some control agents against Aphis gossypii Glover on cucumber plants during summer plantation, season 2010 in Benisuef governorate.

\begin{tabular}{|c|c|c|c|c|c|c|c|c|c|c|c|c|}
\hline \multirow[b]{2}{*}{ Treatments } & \multirow{2}{*}{$\begin{array}{l}\text { Rate/ } \\
100 \text { litre }\end{array}$} & \multicolumn{11}{|c|}{ Number of aphids/100 leaves and \%reduction after different days from spray } \\
\hline & & $\begin{array}{l}\text { Pre- } \\
\text { spray }\end{array}$ & $\begin{array}{l}\text { One } \\
\text { day }\end{array}$ & $\begin{array}{l}\text { \%reducti } \\
\text { on }\end{array}$ & $\begin{array}{l}\text { Three } \\
\text { days }\end{array}$ & $\begin{array}{c}\text { \%reducti } \\
\text { on }\end{array}$ & $\begin{array}{c}\text { Seven } \\
\text { days }\end{array}$ & $\begin{array}{l}\text { \%reducti } \\
\text { on }\end{array}$ & Ten days & $\begin{array}{l}\text { \%reducti } \\
\text { on }\end{array}$ & $\begin{array}{c}\text { General } \\
\text { mean }\end{array}$ & $\begin{array}{c}\text { General } \\
\text { \%reducti } \\
\text { on }\end{array}$ \\
\hline $\begin{array}{c}\text { Carbosulfan } \\
25 \% \text { WP }\end{array}$ & $150 \mathrm{~g}$ & 1117 & $89^{d}$ & 94.73 & $170^{d}$ & 90.94 & $256^{e}$ & 88.14 & $485^{\mathrm{e}}$ & 80.82 & 250 & 88.65 \\
\hline $\begin{array}{c}\text { Acetamiprid } \\
20 \% \mathrm{SP}\end{array}$ & $25 \mathrm{~g}$ & 1310 & $38^{f}$ & 98.08 & $95^{\mathrm{e}}$ & 95.68 & $171^{\mathrm{f}}$ & 93.24 & $379^{f}$ & 87.22 & 170.75 & 93.55 \\
\hline $\begin{array}{c}\text { Imidacloprid } \\
35 \% \mathrm{SC}\end{array}$ & $75 \mathrm{ml}$ & 1200 & $55^{\mathrm{e}}$ & 96.97 & $175^{d}$ & 91.32 & $301^{d}$ & 87.02 & $665^{d}$ & 75.52 & 299 & 87.70 \\
\hline $\begin{array}{c}\text { Pyrethrins } 5 \% \\
\text { EC }\end{array}$ & $110 \mathrm{ml}$ & 1235 & $579^{b}$ & 68.99 & $753^{b}$ & 63.71 & $1176^{b}$ & 50.71 & $1556^{b}$ & 44.35 & 1016 & 56.94 \\
\hline $\begin{array}{c}\text { Mineral oil } 96 \% \\
\text { EC }\end{array}$ & $1.5 \mathrm{~L}$ & 1280 & $341^{c}$ & 82.38 & $577^{c}$ & 73.17 & $725^{c}$ & 70.68 & $918^{c}$ & 68.32 & 640.25 & 73.63 \\
\hline Untreated & - & 1250 & $1890^{\mathrm{a}}$ & - & $2100^{a}$ & - & $2415^{a}$ & - & $2830^{a}$ & - & - & - \\
\hline L.S.D. at 0.05 & - & - & 6.78 & - & 72.85 & - & 8.24 & - & 26.45 & - & - & - \\
\hline
\end{tabular}

Means in each column followed by the same letter (s) are not significantly different ( $P=0.05$ : Duncan's (1955) multiple range test) 
Concerning the performance of the tested insecticides at different intervals, it was obvious that Acetamiprid, Carbosulfan and Imidacloprid showed the longest persistent action and caused the highest reduction in aphid population till the $10^{\text {th }}$ day relaxation period after application. On the other hand, Mineral oil and Pyrethrins were the least effective against $A$. gossypii population after ten days of relaxation period.

It could be concluded that Acetamiprid proved to be the most effective insecticide followed by Imidacloprid and Carbosulfan, while Mineral oil and Pyrethrins gave approximately moderate reduction.

\section{Effect of tested insecticides on cucumber yield:}

Data in Table (4) showed that the highest fruit weights (14.82 and 17.55 tons/feddan "Behira" \& 14.56 and 16.12 ton/feddan "Benisuef") was collected from plots treated with Acetamiprid during 2009 and 2010, respectively. The least yield was harvested from the untreated plots (7.15 and 7.93 ton/feddan "Behira"\& 5.59 and 7.28 ton/feddan "Benisuef") during 2009 and 2010, respectively. All treatments were differed significantly from the untreated check. It could be concluded that the highest cucumber yield was collected from plots treated with Acetamiprid followed by Carbosulfan, Imidacloprid, Mineral oil and Pyrethrins which gave the lowest yield.

Finally, it could be concluded that Acetamiprid proved to be the most effective insecticide against $A$. gossypii and gave the highest cucumber yield.

Our results suggest that Acetamiprid, Imidacloprid, Carbosulfan and Mineral oil can provide a satisfactory control of $A$. gossypii.

Table 4. Effect of tested insecticides on the cucumber yield (ton/feddan) during summer plantation, seasons of 2009 and 2010 in Behira and Benisuef governorates.

\begin{tabular}{|c|c|c|c||c|c|c|}
\hline \multirow{2}{*}{ Treatments } & \multicolumn{3}{|c|}{ Yield (ton/feddan) } \\
\cline { 2 - 7 } & \multicolumn{3}{|c|}{ Behira } & \multicolumn{3}{c|}{ Benisuef } \\
\cline { 2 - 7 } & 2009 & 2010 & $\begin{array}{c}\text { General } \\
\text { mean }\end{array}$ & 2009 & 2010 & $\begin{array}{c}\text { General } \\
\text { mean }\end{array}$ \\
\hline Carbosulfan 25\% WP & 14.43 & 13.78 & 14.11 & 13.0 & 14.17 & 13.59 \\
\hline Acetamiprid 20\% SP & 14.82 & 17.55 & 16.19 & 14.56 & 16.12 & 15.34 \\
\hline Imidacloprid 35\% SC & 12.48 & 13.26 & 12.87 & 11.70 & 13.0 & 12.35 \\
\hline Pyrethrins 5\% EC & 8.58 & 10.14 & 9.36 & 7.67 & 8.45 & 8.06 \\
\hline Mineral oil 96\% EC & 11.70 & 12.74 & 12.22 & 11.18 & 12.61 & 11.90 \\
\hline Untreated & 7.15 & 7.93 & 7.54 & 5.59 & 7.28 & 6.44 \\
\hline L.S.D. at 0.05 & 0.27 & 0.33 & - & 0.42 & 0.30 & - \\
\hline
\end{tabular}


Such results are in harmony with that obtained by Loebenstein et. al. (1970) who reported that more frequent sprays were needed to be applied to the seedlings of papers until flowering then more spaced sprays were needed until final harvest especially when infestation by aphids and plant infection occurred late. Shalaby and Yousif-Khalil (1992) they found that Carbosulfan was effective against aphid and caused increase in broad bean yield. According to Webb (1993), oil sprays delayed the primary infection but the rapid vegetative growth of more healthy plants made it difficult to adequately protect foliage and spacing between plants increased the effectiveness of oil application, with a good coverage of leaves by a high spray pressure of oil. Imidacloprid acts on the nicotinic acetylcholine receptor, causing the insect to reduce or stop feeding, and reduces mobility (Gourment et. al. , 1994 \& Boiteau and Osbron, 1997). The obtained results are agreement with those results obtained by Nucifora (1998) when applied Imidacloprid to control Aphis gossypii associated with small colonies of Myzus persicae infestation, he mentioned that Imidacloprid activity was very satisfactory. Omar et. al. (2001), stated that Imidacloprid the most potent insecticide in reducing Aphis gossypii population followed by Malathion then mineral oil by applying two sprays at two week intervals or 3 sprays at one week intervals. Rana et. al. (2007) tested Imidacloprid , Carbosulfan and Bifenthrin and found all tested insecticides performed better results against aphid as compared to untreated plots, yet Carbosulfan proved to be the most effective insecticide.

\section{REFERENCES}

1. Blackman, R. L. and V. F. Eastop. 2000. Aphids on the world's crops: An Identification and Information Guide, $2^{\text {nd }}$ ed. John Wiley and Sons Ltd., Chichester, 466 pp.

2. Boiteau, G. and W. P. L. Osbron. 1997. Behavioural effects of Imidacloprid, a new nicotinyl insecticide, on the potato aphid, Macrosiphum euphorbiae (Thomas) (Homoptera : Aphididae). Can. Entomol., 129: 241-249.

3. Duncan, D. B. 1955. Multiple range and multiple F-test. Biometrics, 11: 1-42.

4. Farag, N. A. and M. A. Gesraha. 2007. Impact of four insecticides on the parasitoid wasp, Diaertiella rapae and its host aphid, Brevicoryne brassicae under laboratory conditions. Res. J. Agric. Biol. Sci., 3 (5): 529-533.

5. Girousse, C., B. Moulia, W. Silk and J.L. Bonnemain. 2005. Aphid infestation causes different changes in carbon and nitrogen allocation in alfalfa stems as well as different inhibitions of longitudinal and radial expansion. Plant Physiol., 137: $1474-1484$. 
6. Gourment, C., A.D. Hewing, F.L. Koib and C.A.S. Myth. 1994. Effect of Imidacloprid on non-flight movement of Rhopalosiphum padi and subsequent spread of barley yellow dwarf virus. Plant Dis., 78: 1098-1101.

7. Henderson, C.F. and E.W. Tilton. 1955. Test with acaricides against the brown wheat mite. J. Econ. Entomol., 48 : 157-161.

8. Loebenstein, G., M. Alper and S. Levy. 1970. Field tests with oil sprays for the prevention of aphid-spread viruses in peppers. Phytopathology, 60: 212-215.

9. Lu, W. N., Y. T. Wu and M. H. Kuo. 2008. Development of species-specific primers for the identification of aphids in Taiwan. Appl. Entomol., Zool., 43 (1): 91-96.

10. Nucifora, S. 1998. Imidacloprid against aphids on citrus. Atti, Giornate Fitopatologiche, Scicli e Ragusa, 3-7 maggio, 185-190.

11. Omar, B. A., M.A. Zedan and M.K.E. Al-Ansari. 2001. The aphid predators relationship in squash fields influenced by using insecticides. J. Agric. Sci. Mansoura Univ., 26 (4): 2363-2372.

12. Pegadaraju, V., C. Knepper, J. Reese and J. Shah. 2005. Premature leaf senescence modulated by the Arabidopsis PHYTOALEXIN DEFICIENT4 gene is associated with defence against the phloem-feeding green peach aphid. Plant Physiol., 139: 1927-1934.

13. Rana, Z. A., M. A. Shahazad, N. A. Malik and A. Saleem. 2007. Efficacy of different insecticides and Dc-tron plus against mustard aphid, Lipaphis erysimi (Kalt). J. Agric. Res., 45 (3): 221-224.

14. Shalaby, A. A. and S. I. Yousif-Khalil. 1992. Effect of insecticidal application on some pests attacking broad bean. J. Appl. Sci., Egypt, 7 (4): 630-641.

15. Toperkaygin, A., F. Cota and G. Görür. 2008. Contribution to the aphid (Homoptera : Aphididae) species damaging on woody plants in Bartin, Turkey. Int. J. Natural Eng. Sci., 2 (1): 83-86.

16. Von Dohlen, C. D., C.A. Rowe and O. E. Heie. 2006. A test of morphological hypotheses for tribal and subtribal relationships of Aphidinae (Insecta : Hemiptera : Aphididae) using DNA sequences. Mol. Phylogenet. E Vol 38: 316329.

17. Webb, S. E. 1993. Effect of oil and insecticide on epidemics of potyviruses in watermelon in Florida. Plant Dis., 77: 869-874. 


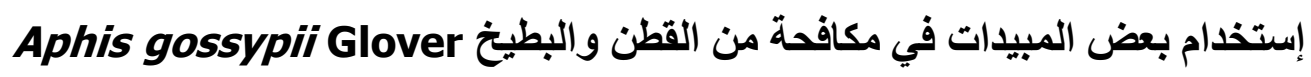
علي نباتات الخيار مع الإشارة الي المحصول

منى عبد الحميد محمد ، همام بخيث همام

معهُ بحوث وقابة النباتاتـ مركز البحوث الزراعية ـ الدقي- جيزة- 12618 مصر

تم إجر اء تجارب حقلية لار اسة تأثير فاعلية خمسة مبيدات حشرية (مارشال - فابكومور -

إيميدور - بايريثرم - زيت معدني) ضد حشرة من القطن والبطيخ الذي يصيب نباتات الخيار في كل

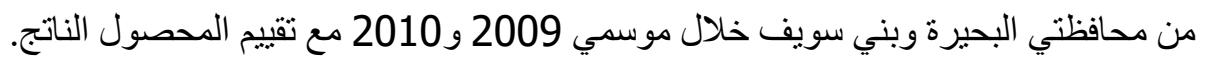

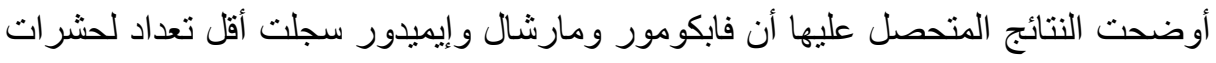
المن في كل من محافظتي البحيرة وبني سويف خلال موسمي الزراعة الصيفية 2009و 2010 بينما أعطي الزيت المعدني تأثير منوسط علي تعداد حشرات المن. و علي العكس كان مبيد بايريثرم أقل تأثير

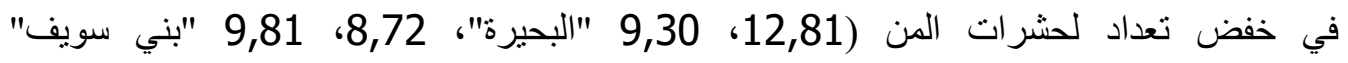
أفر اد/ورقة/موسم) خلال موسمي 2009 و2010 علي التو الي. كما أظهرت النتائج فروق معنوية بين النئ

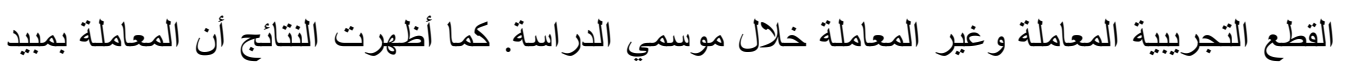

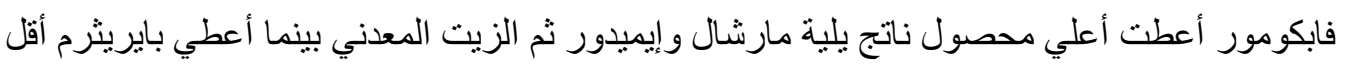
محصول ناتج.

أوضحت النتائج أن المركبات المختبرة (فابكومور ومارشال و إيميدور) أعطت أعلي نسبة

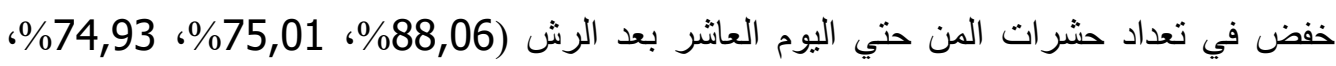

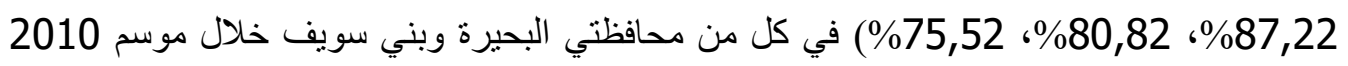

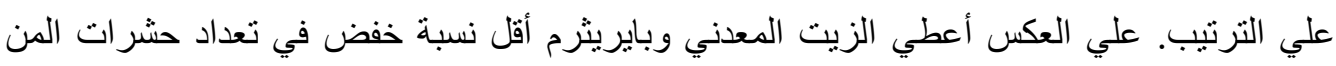

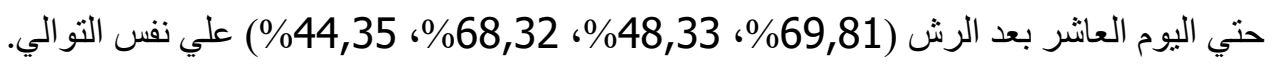

